\title{
Lumbrical-interosseous latency comparison test as a highly sensitive tool in diagnosing mild and severe carpal tunnel syndrome
}

\author{
Wysoka czułość testu oceniającego różnicę latencji ruchowej pomiędzy drugim \\ mięśniem glistowatym a drugim mięśniem międzykostnym (2LI-DML) w diagnostyce \\ zespołu cieśni nadgarstka o niewielkim i znacznym stopniu zaawansowania
}

MARTA BANACH ${ }^{1, \text { A-F }}$, ANTONI FERENS', B, F, JAKUB ANTCZAK1, C, F, DOROTA GRIBBIN², 3, E, F

${ }^{1}$ Department of Neurology Jagiellonian University Medical College in Krakow

${ }^{2}$ Columbia University College of Physicians and Surgeons, Department of Rehabilitation and Regenerative Medicine

${ }^{3}$ Physical Medicine and Rehabilitation Section, Robert Wood Johnson University Hospital at Hamilton

A - Study Design, B - Data Collection, C - Statistical Analysis, D - Data Interpretation, E - Manuscript Preparation, $\mathbf{F}$ - Literature Search, $\mathbf{G}$ - Funds Collection

Summary Background. The diagnosis of the very early and very advanced stages of carpal tunnel syndrome (CTS) is still challenging.

Objectives. We evaluated whether a nerve conduction study measuring the difference in latencies between the second lumbrical and dorsal interosseous muscles (2LI-DML) is useful for diagnosing mild and severe CTS.

Material and methods. The study included 25 patients ( 25 hands) clinically diagnosed with severe CTS and 42 patients (51 hands) with mild CTS. The control group consisted of 60 healthy volunteers. A total of 172 patients (253 hands) gave their consent to participate in the study. The main outcome measures were the percentage of clinical diagnoses of mild and severe CTS, confirmed using a standard electrophysiological method (the sensory nerve conduction study from at least one median innervated digit and the difference between median and ulnar sensory latencies [D4M-D4U]) and the percentage of clinical diagnoses of mild and severe CTS confirmed with the 2LI-DML test as an alternative electrophysiological method.

Results. In patients with mild CTS, 2LI-DML and D4M-D4U were increased in $90 \%$ and $67 \%$ of the hands, respectively. Antidromic sensory nerve conduction from the wrist to digits 1,3, and 4 was abnormal in $57 \%, 45 \%$, and $47 \%$ of the hands, respectively. In patients with severe CTS, 2 LI-DML was abnormal in $96 \%$ of the patients. In $4 \%$ of the patients ( 1 hand), the response could not be obtained.

Conclusions. Our findings suggest that the 2LI-DML test is a sensitive and useful method for diagnosing CTS, regardless of its severity.

Key words: ulnar nerve, median nerve, carpal tunnel syndrome.

Streszczenie Wstęp. Największe trudności diagnostyczne sprawiają pacjenci z objawami wczesnego oraz znacznego stopnia uszkodzenia nerwu pośrodkowego w kanale nadgarstka.

Cel pracy. Ocena przydatności testu oceniającego różnicę końcowej latencji ruchowej między drugim mięśniem glistowatym a drugim mięśniem międzykostnym (test 2LI-DML) w diagnostyce zespołu cieśni nadgarstka o niewielkim i znacznym stopniu zaawansowania.

Materiał i metody. Badania przeprowadzono w grupie 25 pacjentów ( 25 rąk) o znacznym stopniu zaawansowania oraz w grupie 42 pacjentów (51 rąk) o minimalnym stopniu zaawansowania. Grupę kontrolną stanowiło 60 zdrowych ochotników. U 172 pacjentów (235 rąk) włączonych do badania z objawami klinicznymi zespołu cieśni nadgarstka oraz w wyodrębnionej grupie o niewielkim oraz znacznym stopniu zaawansowania przeprowadzono ocenę czułości testu oceniającego latencję czuciową kolejno na czterech palcach unerwionych przez nerw pośrodkowy oraz wykonano dodatkowo test oceniający różnicę latencji czuciowej między nerwem pośrodkowym i łokciowym na odcinku nadgarstek-4. palec (test D4M-D4U). Standardowy protokół badania został poszerzony o dodatkowy test 2LI-DML.

Wyniki. W grupie pacjentów z niewielkiego stopnia uszkodzeniem nerwu pośrodkowego najwyższą czułość uzyskał test 2LI-DML (90\%) oraz test D4M-D4U (67\%). Mniejszą, ale porównywalną czułość uzyskały testy oceniające latencję czuciową na odcinku nadgarstek-1., 3. i 4. palec (57\%, 45\% i 47\%). W grupie pacjentów o znacznym stopniu zaawansowania ZCN, czułość testu 2LI-DML była wysoka i wynosiła 96\%. Brak odpowiedzi ruchowej wykazano tylko w 1 przypadku (4\%).

Wnioski. Test 2LI-DML jest bardzo czułą i przydatną metodą do oceny niewielkiego oraz znacznego stopnia uszkodzenia nerwu pośrodkowego w kanale nadgarstka.

Słowa kluczowe: zespół cieśni nadgarstka, nerw pośrodkowy, nerw łokciowy. 


\section{Background}

Median nerve entrapment neuropathy (carpal tunnel syndrome or (TS) is one of the most common entrapment neuropathies [1-4]; typical signs and symptoms include paresthesia, numbness, pain, weakness, positive Tinel's sign, positive Phalen's test, and, in extreme cases, thenar muscle atrophy $[2,4,5]$. The current gold standard for diagnosing CTS requires the confirmation of clinical signs and symptoms by an electrophysiological examination [6]. The guidelines for an electrophysiological diagnosis of CTS were established in 1993 by the American Academy of Neurology (AAN), the American Association of Electrodiagnostic Medicine (AAEM), and the American Academy of Physical Medicine and Rehabilitation (AAPM\&R); these guidelines were updated in 2002 [7-10]. Prolonged sensory latency (SL) from the wrist to the digits that are innervated by the median nerve is a standard diagnostic criterion for CTS $[7,8,10]$. If this criterion is not met, the AAN/AAEM/AAPM\&R guidelines recommend two more sensitive techniques: the first one based on comparing median and unilateral ulnar or radial nerves, and the other - on the short segmental nerve conduction study [7-10]. Despite these established diagnostic guidelines and many different methods for testing nerve conduction, the most problematic challenge is the diagnosis of the very early and very advanced stages of CTS. Therefore, more sensitive, easier-to-perform, and quicker methods have been developed for the past few years. One of the most popular method is to measure the difference between the median motor latency to the second lumbrical muscle and the ulnar motor latency to the second interosseous muscle (2LI-DML). Although initially controversial $[11,12]$, the 2 LI-DML test is now generally accepted as being reliable for diagnosing CTS at very early and very advanced stages [13-19]. The aim of this study was to evaluate the usefulness of the $2 \mathrm{LI}-\mathrm{DML}$ test in the diagnosis of mild and severe CTS in a large Polish population and to propose this electrophysiological test as a standard diagnostic tool in patients in very advanced stages of CTS.

\section{Material and methods}

Examinations were conducted in 172 patients (253 hands) with clinical symptoms of CTS, including 131 women and 41 men, aged from 19 to 84 years (mean age, 51.8 \pm 17 years).

All patients were Caucasians. The control group consisted of 60 healthy volunteers including 40 women and 20 men, aged from 23 to 53 years (mean age, $38.5 \pm 17$ years). Written informed consent was obtained from all patients and volunteers. Clinical and electrophysiological diagnoses of CTS were made according to the AAN criteria [7].

The electrophysiological test required to meet these criteria includes:

I. Measurement of antidromic sensory onset latency (SL) from the wrist to digit 2 (D2), using a distance of $13 \mathrm{~cm}$ (SL-D2).

In each case, additional latency measurements were made for the remaining digits that are innervated by the median nerve as follows:

1) antidromic SL between the wrist and D1, using a distance of $10 \mathrm{~cm}$ (SL-D1),

2) antidromic SL between the wrist and D3, using a distance of $13 \mathrm{~cm}$ (SL-D3),

3) antidromic SL between the wrist and D4, using a distance of $14 \mathrm{~cm}$ (SL-D4).

II. Measurement of distal motor latency (DML) from the wrist to the abductor pollicis brevis (APB) muscle, using a distance of $6.5 \mathrm{~cm}$ (DML-APB).

III. Measurement of the difference in median-ulnar antidromic SL between the wrist and D4, using the same dis- tance of $14 \mathrm{~cm}$ that was used during stimulation of the median and ulnar nerves (D4M-D4U).

This standard examination protocol was extended to include the following additional electrophysiological test:

IV. The $2 \mathrm{LI}-\mathrm{DML}$ test comparing the median DML recorded from the second lumbrical muscle (2L) with the ulnar motor latency recorded from the second dorsal interosseous muscle (2I).

The nerves were stimulated at the wrist using identical distances of $10 \mathrm{~cm}$, and compound muscle action potentials from both muscles ( $2 \mathrm{~L}$ and $2 \mathrm{I}$ ) were recorded in the midpoint between the second and third metacarpal bones [13].

Severe CTS was diagnosed when neither sensory response from digits 1 to 4 nor motor response from the thenar muscles was obtained. Mild CTS was diagnosed when DML to the APB muscle and antidromic SL to digit 2 were normal, but the results of the other tests described above were abnormal (and there were no other causes of these abnormalities than CTS).

To exclude polyneuropathy, routine conduction velocity in the sensory and motor fibers of the ipsilateral ulnar nerve was measured in all patients. The electrophysiological examinations were performed with a Medelec Synergy electromyograph (Medelec, England) using surface stimulating and recording electrodes. For consistency, the nerve conduction studies were all performed by the same neurologist. The filters were set at $2 \mathrm{~Hz}$ and $10 \mathrm{kHz}$ for the motor studies and $20 \mathrm{~Hz}$ and $2 \mathrm{kHz}$ for the sensory studies, and sweep speed was set at $1 \mathrm{~ms} /$ division. The sensory conduction data were captured using surface ring recording electrodes, and the motor conduction data were captured with surface disk electrodes of $1 \mathrm{~cm}$ in diameter. The median and ulnar nerves were stimulated supramaximally with stimuli of $0.2 \mathrm{~ms}$ in duration, delivered by a hand-held bipolar stimulator. The sensory responses used to measure the onset latency were the average of 16 trials, and a gain setting of $10 \mu \mathrm{V} / \mathrm{divi}$ sion was used. The latencies were rounded to the nearest $0.05 \mathrm{~ms}$. Hand skin temperature $\left(32-34^{\circ} \mathrm{C}\right)$ was monitored throughout the study.

Data were analyzed using StatSoft, Inc. (2008) STATISTICA version 8.0 (data analysis software system; www.statsoft. com). The parameters of the control and patient groups were quantified using descriptive statistics. Mean values, standard deviation (SD), and ranges (minimum and maximum) were calculated. The values between the groups were compared using the Mann-Whitney test. The sensitivity of each test in diagnosing CTS was calculated with the following formula: sensitivity $=[$ (the number of patients with a positive test for $\mathrm{CTS}$ )/(the number of hands with a clinical diagnosis of CTS according to the AAN)] $\times 100$.

Additionally, we analyzed the combined sensitivity of SL-D1, SL-D2, SL-D3, and SL-D4 (all digits innervated by the median nerve) in diagnosing mild and severe CTS.

\section{Results}

The latency or latency difference values (including mean $\pm \mathrm{SD}$ and minimum and maximum values, with assumed standards) in control subjects are presented in Table 1.

The mean motor and sensory latencies (SL-D1, SL-D2, SL-D3, SL-D4, and DML-APB) were longer and motor-sensory distal latency differences (2LI-DML and D4M-D4U) were greater in the CTS group than in the control group (Tab. 2).

The abnormal results, allowing the electrophysiological diagnosis of CTS, were found in 246 cases $(97 \%)$ using the 2LI-DML test; in 235 cases (93\%) using the D4M-D4U test; in 194 cases $(77 \%)$ using the SL-D2 test; and in 170 cases $(67 \%)$ using the with DML-APB test. In 170 cases (67\%), all 


\begin{tabular}{|c|c|c|c|}
\hline $\begin{array}{l}\text { Name of } \\
\text { Test }\end{array}$ & Mean \pm SD & $\begin{array}{l}\text { Range } \\
\text { [min-max] }\end{array}$ & $\begin{array}{l}\text { Upper limit value } \\
\leq \text { mean }+2 \mathrm{SD}\end{array}$ \\
\hline SL-D1 & $2.20 \pm 0.15$ & $1.80-2.70$ & 2.50 \\
\hline SL-D2 & $2.37 \pm 0.30$ & $1.80-2.98$ & 2.97 \\
\hline SL-D3 & $2.30 \pm 0.35$ & $2.20-3.00$ & 3.00 \\
\hline SL-D4 & $2.38 \pm 0.37$ & $2.10-3.20$ & 3.10 \\
\hline DML-APB & $3.40 \pm 0.48$ & $2.75-4.35$ & 4.40 \\
\hline D4M-D4U & $0.20 \pm 0.12$ & $0.10-0.45$ & 0.50 \\
\hline 2LI-DML & $0.21 \pm 0.10$ & $0.05-0.40$ & 0.41 \\
\hline
\end{tabular}

SL-D1 - antidromic sensory latency to digit 1; SL-D2 - antidromic sensory latency to digit 2; SL-D3 - antidromic sensory latency to digit 3; SL-D4 - antidromic sensory latency to digit 4; DML-APB - distal motor latency to the abductor pollicis brevis muscle; D4M-D4U - difference between the median and ulnar antidromic sensory latency to digit 4; $2 \mathrm{LI}-\mathrm{DML}$ - difference between distal motor latencies of the second lumbrical and second interosseous muscles.

\begin{tabular}{|c|c|c|c|}
\hline \multirow{2}{*}{ Test } & \multicolumn{3}{|c|}{ Latency or latency difference values (in ms) } \\
\hline & $\begin{array}{l}\text { CTS group } \\
\text { mean } \pm \text { SD }\end{array}$ & $\begin{array}{l}\text { Control group } \\
\text { mean } \pm \text { SD }\end{array}$ & $p$ \\
\hline 2LI-DML & $2.38 \pm 2.12$ & $0.15 \pm 0.12$ & 0.000001 \\
\hline D4M-D4U & $1.66 \pm 1.28$ & $0.18 \pm 0.11$ & 0.000001 \\
\hline SL-D1 & $3.29 \pm 1.60$ & $2.20 \pm 0.15$ & 0.00635 \\
\hline SL-D2 & $3.69 \pm 0.85$ & $2.37 \pm 0.30$ & 0.00083 \\
\hline SL-D3 & $3.83 \pm 0.94$ & $2.30 \pm 0.35$ & 0.01230 \\
\hline SL-D4 & $4.08 \pm 1.30$ & $2.38 \pm 0.37$ & 0.03773 \\
\hline DML-APB & $5.54 \pm 1.91$ & $3.43 \pm 0.38$ & 0.000001 \\
\hline
\end{tabular}

2LI-DML - difference between distal motor latencies of the second lumbrical and second interosseous muscles; D4M-D4U - difference between the median and ulnar antidromic sensory latency to digit 4; SL-D1 - antidromic sensory latency to digit 1; SL-D2 - antidromic sensory latency to digit 2; SL-D3 - antidromic sensory latency to digit 3; SL-D4 - antidromic sensory latency to digit 4; DML-APB - distal motor latency to the abductor pollicis brevis muscle.

the six tests (ie, SL-D1, SL-D2, SL-D3, SL-D4, D4M-D4U, and $2 \mathrm{LI}-\mathrm{DML}$ ) gave abnormal results. The abnormal result in the $2 \mathrm{LI}$-DML test was recorded in each case of abnormalities in standard tests (SI-D1, SL-D2, SL-D3, SL-D4, and DMLAPB) as well as in the D4M-D4U test. It was also recorded in 52 cases where there were no abnormalities in standard tests and in 11 cases where no abnormalities were observed in the D4M-D4U test. The normal results in the 2LI-DML test were recorded in seven cases. In none of the cases were the results abnormal in other tests. Motor response from $2 \mathrm{~L}$ was absent in one case, and from the APB muscle, it was absent in 25 cases. The sensory response from D1 was absent in 79; from D2, in 73; from D3, in 89; and from D4, in 95 cases. The patient in whom no motor response was recorded in the 2LI-DML test showed no response in the other tests as well. The results of each test in the diagnosis of CTS are shown in Figure 1.

The sensitivity of the 2LI-DML test in the whole CTS group was $97 \%$, which was higher than the sensitivity of the standard DML-APB $(67 \% ; p=0.01)$ and SL-D2 $(77 \%$; $p=0.02)$ tests. The combined sensitivity of SL-D1, SL-D2, SL-D3, and SL-D4 was $89 \%$, which was comparable to the sensitivity of SL-D1 (89\%), SL-D3 (87\%), and SL-D4 (88\%).

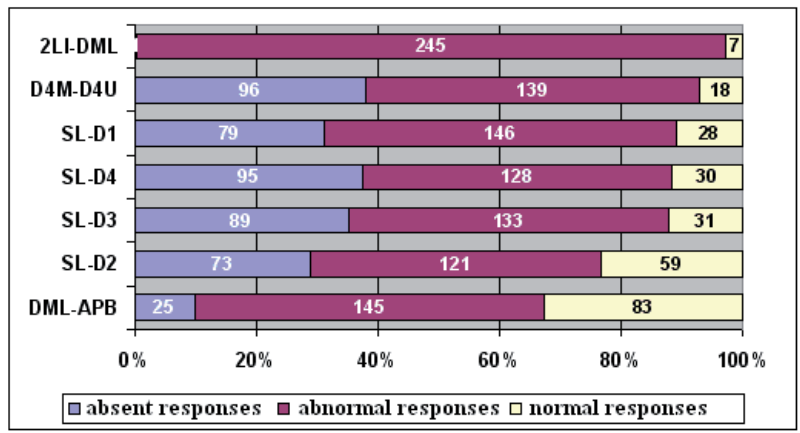

Figure 1. Comparison of the results of various methods of electrophysiological evaluation of carpal tunnel syndrome (CTS)

\section{Sensitivity of 2LI-DML in severe CTS}

The severe-CTS group consisted of 25 patients ( 25 hands) including 20 women and 5 men, aged from 40 to 63 years (mean age, $62.9 \pm 11.7$ years). The sensitivity of the $2 \mathrm{LI}$ -DML test in severe CTS was $96 \%$. In one case, no response was obtained.

\section{Sensitivity of 2LI-DML in mild CTS}

The mild-CTS group consisted of 42 patients (51 hands) including 30 women and 12 men, aged from 19 to 42 years (mean age, $31.85 \pm 13.26$ years). The sensitivity of the $2 \mathrm{LI}$ -DML test in mCTS was $90 \%$.

The sensitivities of particular tests for all patients and for both subgroups are presented in Table 3.

Table 3. Comparison of the sensitivities of performed tests
between the entire patient group and eCTS and mCTS sub-
groups
\begin{tabular}{l|l|l|l|}
\hline Test & $\begin{array}{l}\text { All } \\
\text { hands }\end{array}$ & eCTS & mCTS \\
\hline 2LI-DML & $97 \%$ & $97 \%$ & $90 \%$ \\
\hline D4M-D4U & $93 \%$ & absent responses & $67 \%$ \\
\hline SL-D1 & $89 \%$ & absent responses & $57 \%$ \\
\hline SL-D3 & $87.8 \%$ & absent responses & $45 \%$ \\
\hline SL-D4 & $88 \%$ & absent responses & $47 \%$ \\
\hline SL-D2 & $77 \%$ & absent responses & normal responses \\
\hline DML-APB & $67 \%$ & absent responses & normal responses \\
\hline
\end{tabular}

eCTS - extreme carpal tunnel syndrome; mCTS - minimal carpal tunnel syndrome; 2LI-DML - difference between distal motor latencies of the second lumbrical and second interosseous muscles; D4M-D4U - difference between the median and ulnar antidromic sensory latency to digit 4; SL-D1 - antidromic sensory latency to digit 1; SL-D3 - antidromic sensory latency to digit 3; SL-D4 - antidromic sensory latency to digit 4: SL-D2 - antidromic sensory latency to digit 2; DML-APB - distal motor latency to the abductor pollicis brevis muscle.

\section{Discussion}

The main finding of the present study is that $2 \mathrm{LI}-\mathrm{DML}$ is the most sensitive electrophysiological test, regardless of the degree of CTS. The exceptionally high sensitivity of the 2LI-DML test in our study confirms that a large percentage of patients received an accurate clinical and electrophysiological diagnosis of CTS. Specifically, the clinical diagnosis of CTS was confirmed in $93 \%$ of all patients by at least one of the six electrodiagnostic tests used in the study. The sensory SL-D2 and motor DML-APB tests, which are historically the earliest and most frequently applied tests, actually had the lowest sensitivity, which is in line with the findings published in other reports $[2,7,8,10,20-26]$. 
Consistent with the studies by Trojaborg et al. [15], Macdonell et al. [24], Kothari et al. [25], and Banach et al. [27], we obtained the highest sensitivity when measuring SL between the wrist and D1. However, in some studies, the sensitivities of the SLs between the wrist and D3/D4 were comparable $[16,24,25,28]$. In the entire CTS group as well as in the mCTS subgroup, the sensitivity of the D4M-D4U test was slightly higher than in previous studies, which reported a sensitivity of $77 \%$ to $82 \%$ in CTS and of $44 \%$ to $52 \%$ in mCTS $[11,23,29,30]$.

Based on the clinical and electrophysiological findings, 25 of our CTS patients $(10 \%)$ had a severe median nerve lesion. Our results are similar to those of Löscher et al. [16] (36 patients $[11.3 \%]$ ), but are much higher than those of Preston and Logigian [13], Sheean et al. [14], and Boonyapisit et al. [18] (2\%, $3 \%$, and $2.4 \%$, respectively).

\section{The sensitivity of $2 \mathrm{LI}-\mathrm{DML}$}

In the mCTS group, the sensitivity of the 2LI-DML test was comparable to the results of Preston and Logigian [13] (84\%), and higher than those of Uncini et al. [11] (40\%). We have no explanation for the lower value reported by Uncini et al. [11] Several studies of the 2LI-DML test revealed a sensitivity in the range of $78 \%$ to $98 \%$, regardless of CTS progression [12-19, 31, 32].

The widely varying sensitivity of electrophysiological tests in the diagnosis of CTS depends on both the severity of median nerve entrapment neuropathy in the study population and differences in electrophysiological techniques and statistical methodologies [33]. The different references of the control groups and cut-off values also play a role in test performance [30]. The 2LI-DML technique used in our study is similar to that used by Preston and Logigian [13]. Based on our experience, the upper limit of a normal 2LI-DML test $(0.4 \mathrm{~ms})$ is identical to that established by Preston and Logigian [13] and Sheean et al. [14]. However, Uncini et al. [11], Trojaborg et al. [15], and Löscher et al. [16] established the upper limit of a normal 2LI-DML test at $0.5 \mathrm{~ms}$.

A direct comparison of the sensory test results obtained from various electromyography laboratory facilities is difficult owing to the lack of test standardization. The sensory nerve conduction technique used in our study is similar to the one used by Löscher et al. [16], except that they stimulated the median and ulnar nerves $2 \mathrm{~cm}$ proximal from the anatomical landmark at the wrist, whereas we used the same distance as with antidromic stimulation. Uncini et al. [11], Sheean et al. [14], and Trojaborg et al. [15] calculated sensory nerve conduction velocity (instead of distal latency) using orthodromic stimulation.

Regardless of the examination technique used and the selection of patient and control groups, the results obtained by all authors consistently indicate that $2 \mathrm{LI}-\mathrm{DML}$ is the most sensitive diagnostic test, especially in patients with severe CTS. The $2 \mathrm{LI}-\mathrm{DML}$ test is also a very sensitive method for early CTS, being comparable to the most sensitive median-ulnar palmar mixed test based on comparative techniques [13, 34].
We have no adequate explanation for the higher sensitivity of the 2LI-DML test that we obtained in our patients with mild CTS as compared with the findings of most authors. In 1945, Sunderland et al. [35] described a very precise funicular topography of the median nerve in the distal portion of the carpal tunnel and showed that two groups of motor fibers (predominate deep and mild superficial) innervate the lumbrical muscles. The superficial motor fibers lie close to sensory fibers that innervate the first (D1), third (D3), and fourth (D4) digits, and this may explain the abnormal values found in mild focal demyelination $[15,36]$. The sensory fibers that innervate the second digit (D2) are more centrally located, being close to the motor nerves that innervate the thenar muscles (DML-APB).

The deep location of the motor fibers that innervate the lumbrical muscles (2LI) explains the preservation of motor action potentials from $2 \mathrm{LI}$ in severe cases of CTS, in which we were unable to obtain motor responses from atrophic thenar muscles [35]. Subsequently, Logigian et al. [36] and Yates et al. [37] confirmed that the deep position of the motor fibers protects against the compression effect. Additional advantages of this comparative study are that the nerves being tested have axons of similar size and the muscles are located next to each other; therefore, the temperature needs not be closely monitored [13]. Moreover, the electrodes remain in fixed positions, and only the stimulation site changes. We therefore confirm that the 2LI-DML test is accurate, fast, and easy to perform.

\section{Conclusions}

2LI-DML is the most sensitive comparative test, regardless of the degree of entrapment neuropathy (whether minimal or severe).

$2 \mathrm{LI}-\mathrm{DML}$ is a useful test in the diagnosis of CTS since it is accurate, time-efficient, easy to perform, and it can be used as a screen test.

In extreme CTS, the response was only obtainable at the second lubrical muscle which allows to confirm CTS.

\section{Acknowledgements}

The study was conducted in the Electromyography Laboratory of the Neurological Department, Jagiellonian University Medical College in Kraków, Poland.

This work was presented in part at the 56th American Academy of Neurology Annual Meeting, April 24 - May 1, 2004, in San Francisco, California. Part of the findings has already been published in the studies covering other issues. I would like to thank Lewis P. Rowland, Dale J. Lange and Werner Trojaborg for teaching me this new electrophysiological method during the internship at Neurological Institute Columbia University, Medical Center New York and for encouraging us to test its sensitvity and specificity in Polish population.

We are grateful to Justyna Znój and Elżbieta Guziak for their excellent technical support.

Source of funding: The research was performed as a part of the study: No. DNWZ-WL-501/KL/230/L in the Department of Neurology, Jagiellonian University Medical College.

Conflict of interest: The authors declare no conflict of interests.

\section{References}

1. de Krom MC, Knipschild PG, Kester AD, et al. Carpal tunnel syndrome: prevalence in the general population. J Clin Epidemiol 1992; 45: 373-376.

2. Stevens JC. AAEM minimonograph \#26: the electrodiagnosis of carpal tunnel syndrome. Muscle Nerve 1997; 20: 1477-1486.

3. Atroshi I, Gummesson C, Johnsson R, et al. Prevalence of carpal tunnel syndrome in a general population. JAMA 1999; 282: $153-158$. 
4. Papanicolaou GD, McCabe SJ, Firrell J. The prevalence and characteristics of nerve compression symptoms in the general population. J Hand Surg Am 2001; 26: 460-466.

5. Banach M, Gribbin D, Zajaczkowska A. Clinical and electrophysiological correlations concerning patients with carpal tunnel syndrome. Przegl Lek 2010; 67: 692-696. Polish.

6. Rempel D, Evanoff B, Amadio PC, et al. Consensus criteria for the classification of carpal tunnel syndrome in epidemiologic studies. Am J Public Health 1998; 88: 1447-1451.

7. American Academy of Neurology, American Association of Electrodiagnostic Medicine and American Academy of Physical Medicine and Rehabilitation. Practice parameter for electrodiagnostic studies in carpal tunnel syndrome (summary statement). Neurology 1993; 43: 2404-2405.

8. American Academy of Neurology, American Association of Electrodiagnostic Medicine and American Academy of Physical Medicine and Rehabilitation. Practice parameter for electrodiagnostic studies in carpal tunnel syndrome (summary statement). Muscle Nerve 2002; 25: 918-922.

9. Jablecki CK, Andary MT, So YT, et al. Literature review of the usefulness of nerve conduction studies and electromyography for the evaluation of patients with carpal tunnel syndrome. Muscle Nerve 1993; 16: 1392-1414.

10. Jablecki CK, Andary MT, Floeter MK, et al. Practice parameter: electrodiagnostic studies in carpal tunnel syndrome. Report of the American Academy of Neurology, American Association of Electrodiagnostic Medicine and American Academy of Physical Medicine and Rehabilitation. Neurology 2002; 58: 1589-1592.

11. Uncini A, Di Muzio A, Awad J, et al. Sensitivity of three median-to-ulnar comparative tests in diagnosis of mild carpal tunnel syndrome. Muscle Nerve 1993; 16: 1366-1373.

12. Seror P. The value of special motor and sensory tests for the diagnosis of benign and minor median nerve lesions at the wrist. Am J Phys Med Rehabil 1995; 74: 124-129.

13. Preston DC, Logigian EL. Lumbrical and interossei recordings in carpal tunnel syndrome. Muscle Nerve 1992; 15: 1253-1257.

14. Sheean GL, Houser MK, Murray NM. Lumbrical-interosseous latency comparison in the diagnosis of carpal tunnel syndrome. Electroenceph Clin Neurophysiol 1995; 97: 285-289.

15. Trojaborg W, Grewal RP, Weimer LH, et al. Value of latency measurements to the small palm muscles compared to other conduction parameters in the carpal tunnel syndrome. Muscle Nerve 1996; 19: 243-245.

16. Löscher WN, Auer-Grumbach M, Trinka E, et al. Comparison of second lumbrical and interosseus latencies with standard measures of median nerve function across the carpal tunnel: a prospective study of 450 hands. J Neurol 2000; 247: 530-534.

17. Walters RJ, Murray NM. Transcarpal motor conduction velocity in carpal tunnel syndrome. Muscle Nerve 2001; 24: 966-968.

18. Boonyapisit K, Katirji B, Shapiro BE, et al. Lumbrical and interossei recording in severe carpal tunnel syndrome. Muscle Nerve 2002; 25: 102-105.

19. Brannegan R, Bartt R. Second lumbrical muscle recordings improve localization in severe carpal tunnel syndrome. Arch Phys Med Rehabil 2007; 88: 259-261.

20. Kimura J. The carpal tunnel syndrome: localization of conduction abnormalities within the distal segment of the median nerve. Brain 1979; 102: 619-635.

21. Carroll GJ. Comparison of median and radial nerve sensory latencies in the electrophysiological diagnosis of carpal tunnel syndrome. Electroencephalogr Clin Neurophysiol 1987; 68: 101-106.

22. De Léan J. Transcarpal median sensory conduction: detection of latent abnormalities in mild carpal tunnel syndrome. Can J Neurol Sci 1988; 15: 388-393.

23. Jackson DA, Clifford JC. Electrodiagnosis of mild carpal tunnel syndrome. Arch Phys Med Rehabil 1989; 70: 199-204.

24. Macdonell RA, Schwartz MS, Swash M. Carpal tunnel syndrome: which finger should be tested? An analysis of sensory conduction in digital branches of the median nerve. Muscle Nerve 1990; 13: 601-606.

25. Kothari MJ, Rutkove SB, Caress JB, et al. Comparison of digital sensory studies in patients with carpal tunnel syndrome. Muscle Nerve 1995; 18: 1272-1276.

26. Padua L, LoMonaco M, Gregori B, et al. Neurophysiological classification and sensitivity in 500 carpal tunnel syndrome hands. Acta Neurol Scand 1997; 96: 211-217.

27. Banach M, Gryz EA, Szczudlik A. Carpal tunnel syndrome. Przegl Lek 2004; 61: 120-125. Polish.

28. Banach $M$, Szczudlik A. The value of sensory latency measured on the four median innervated fingers for the diagnosis of the carpal tunnel syndrome. Neurol Neurochir Pol 2004; 38: 15-20. Polish.

29. Uncini A, Lange DJ, Solomon M, et al. Ring finger testing in carpal tunnel syndrome: a comparative study of diagnostic utility. Muscle Nerve 1989; 12: 735-741.

30. Chang MH, Liu LH, Lee YC, et al. Comparison of sensitivity of transcarpal median motor conduction velocity and conventional conduction techniques in electrodiagnosis of carpal tunnel syndrome. Clin Neurophysiol 2006; 117: 984-991.

31. Preston DC, Ross MH, Kothari MJ, et al. The median-ulnar latency difference studies are comparable in mild carpal tunnel syndrome. Muscle Nerve 1994; 17: 1469-1471.

32. Banach M, Stowik A, Szczudlik A. The value of motor latency difference measurements between the second lumbrical muscle and second interosseous muscle in the diagnosis of carpal tunnel syndrome. Neurol Neurochir Pol 2002; 36: 657-667. Polish.

33. Robinson LR, Micklesen PJ, Wang L. Strategies for analyzing nerve conduction data: superiority of a summary index over single tests. Muscle Nerve 1998; 21: 1166-1171.

34. Kaul MP, Pagel KJ. Value of the lumbrical-interosseous technique in carpal tunnel syndrome. Am J Phys Med Rehabil 2002; 81: 691-695.

35. Sunderland S. Intraneural topography of radial, median and ulnar nerves. Brain 1945; 68: 243-299.

36. Logigian EL, Busis NA, Berger AR, et al. Lumbrical sparing in carpal tunnel syndrome: anatomic, physiologic, and diagnostic implications. Neurology 1987; 37: 1499-1505.

37. Yates SK, Yaworski R, Brown WF. Relative preservation of lumbrical versus thenarmotor fibers in neurogenic disorder. J Neurol Neurosurg Psychiatry 1981; 44: 768-774.

Address for correspondence:

Dr n. med. Marta Banach

Katedra Neurologii UJ CM

ul. Botaniczna 3

31-503 Kraków

Tel.: 607 933-567, 12 424-86-13

Received: 28.10.2015

E-mail: martabanach@yahoo.com

Revised: 30.10.2015

Accepted: 02.11.2015 